\title{
Embedded System Using Field Programmable Gate Array (FPGA) myRIO and LabVIEW Programming to Obtain Data Patern Emission of Car Engine Combustion Categories
}

\author{
Andrizal *, Rivanol Chadry *, Ade Irma Suryani ${ }^{* *}$ \\ \# Department of Electrical Engineering, Politeknik Negeri Padang, Indonesia \\ * Department of Mechanical Engineering, Politeknik Negeri Padang, Indonesia \\ ** Information Technology Department, Politeknik Negeri Padang, Indonesia \\ E-mail: andrizalpoli@gmail.com,rivanolchadry@yahoo.com,lovely_dee30@yahoo.co.id
}

\begin{abstract}
Engine scanner unit is a tool used by mechanical power to know the condition of car engine combustion at the time of tune up process done. The level of elements and compounds that dominant in determining categories of combustion of gasoline fuel car engines through the levels of elements and compounds contained in exhaust emissions are Hydrocarbons (HC), Carbon Monoxide (CO), Carbon Dioxide (CO2) and Oxygen (O2). Complete combustion category produces maximum power, fuel efficiency and emission levels according to the threshold. This occurs when there is a balance of the amount of fuel, airflow and ignition in the engine combustion chamber. Elements and compounds contained in car exhaust emissions can be detected with sensors that are sensitive to elemental levels and these compounds are $\mathrm{HC}, \mathrm{CO}, \mathrm{CO} 2$, and $\mathrm{O} 2$ sensors. This study aims to display the data pattern category of combustion engine through exhaust emissions based on multi sensor detection processed with signal processing system in the form of Fast Fourier Transform (FFT) process. Furthermore, data pattern is performed in accordance with the category of combustion engine detected. The system is designed with embedded system using Field Programable Gate Array (FPGA) myRIO and LabVIEW programming. The results in the test displays the data pattern and the comparison test of the reference data pattern with the data pattern of the detection result. The comparison test result of data pattern similar to $87 \%$ complete engine combustion category and similar to incomplete combustion category $90 \%$.
\end{abstract}

Keywords - embedded system, exhaust gas emission, multi sensor, data pattern.

\section{INTRODUCTION}

One of the routine activities undertaken by vehicle owners is to perform service periodically, so that the vehicle engine performance is always in optimum condition with efficient fuel consumption. Service activities that are often done is tune up the engine combustion. The objective is to obtain maximum fuel efficiency and maximum engine power with exhaust emission conditions which is in accordance with permissible threshold standards often referred to as the category of complete combustion. While the incomplete combustion category is the opposite, it is an undesirable condition such as wasteful fuel, less power and exhaust emissions are not up to standard. To detect and process the setting of the engine combustion engine components of the injection system during a tune-up of engine combustion by a technician carried out by means of an engine scanner unit. This tool comes with an engine burning category indicator

that is generated to make it easier for technicians to read the results. Unlike the carburetor car system, where the ignition setting, air flow and fuel flow is done mechanically. And for the process of setting it when tune up engine burning by technicians done manually without any definite indicator whether complete or incomplete combustion category has achieved. As a result the technicians have difficulty in obtaining the complete burning category and there are often differences in tune-up results between a technician and other technicians.

Some elements and compounds on emissions gasolinefueled discharges value. The level of elements and gas compounds contained in the exhaust emissions will determine the category of engine combustion. Elements and compounds. that is contained in exhaust emissions play an important role to determine the category of combustion engines are carbon monoxide $(\mathrm{CO})$, carbon dioxide $(\mathrm{CO} 2)$, hydrocarbon $(\mathrm{HC})$ and oxygen $(\mathrm{O} 2)$ gases, as shown in Table 1 [1].

The engine combustion conditions according to the desired combustion engine category that determined based on the magnitude values of each element and the detected gas compounds. The magnitude values of each element and gas 
compound will be different for the category of complete combustion and incomplete combustion category $[2,3]$.

TABLE I

ENGINE COMBUSTION CONDITIONS BASED ON ELEMENTAL CONTENT AND EXHAUST GAS COMPOUNDS.

\begin{tabular}{|c|c|c|c|c|}
\hline \multicolumn{4}{|c|}{ Gas Compounds } & \multirow{2}{*}{$\begin{array}{l}\text { Combustion } \\
\text { Category }\end{array}$} \\
\hline $\mathrm{CO}$ & $\mathrm{CO} 2$ & $\mathrm{HC}$ & $\mathrm{O} 2$ & \\
\hline $\mathrm{H}$ & $\mathrm{L}$ & $\mathrm{H}$ & $\mathrm{H}$ & Incomplete \\
\hline $\mathrm{H}$ & $\mathrm{L}$ & $\mathrm{H}$ & $\mathrm{L}$ & Incomplete \\
\hline $\mathrm{L}$ & $\mathrm{L}$ & $\mathrm{L}$ & $\mathrm{H}$ & Incomplete \\
\hline $\mathrm{L}$ & $\mathrm{H}$ & $\mathrm{L}$ & $\mathrm{H}$ & Incomplete \\
\hline $\mathrm{H}$ & $\mathrm{L}$ & $\mathrm{M}$ & $\mathrm{H}$ & Incomplete \\
\hline $\mathrm{H}$ & $\mathrm{H}$ & $\mathrm{H}$ & $\mathrm{H}$ & Incomplete \\
\hline $\mathrm{L}$ & $\mathrm{L}$ & $\mathrm{H}$ & $\mathrm{H}$ & Incomplete \\
\hline $\mathrm{L}$ & $\mathrm{H}$ & $\mathrm{L}$ & $\mathrm{L}$ & Complete \\
\hline
\end{tabular}

H=High, L= Low, M= Medium

Complete combustion results can be detected by the level of exhaust emissions based on the reference standard as shown in Table 1. The condition of complete engine combustion is characterized by the occurrence of a balance between fuel, air and ignition in the combustion chamber characterized by the development of elemental and exhaust emission levels. While said to be incomplete combustion in case of imbalance between air, fuel and ignition of fuel room. Due to incomplete combustion is not maximal engine performance, wasteful fuel, high exhaust emissions and noncompliant exhaust emissions standards [2, 4].

Engine combustion tune-up are carried out periodically to obtain an efficient fuel consumption with maximum power produced.

Car Injection system tune up performed by a mechanic with the help of detector which is often called the engine scanner unit. This system is able to detect and simultaneously petrify the process of tune up the combustion engine setting fuel, air and ignition of the vehicle to obtain perfect combustion conditions. The engine scanner unit works based on the detection of the sensor data installed on the vehicle exhaust emission channel integrated with the Engine Control Unit (ECU) $[5,6]$.

Unlike carburetor system car, which is not equipped with sensor system and ECU so that the combustion system setting is done mechanically.

Table 2 shows the complete combustion category with low $\mathrm{HC}$, low $\mathrm{CO}$, high $\mathrm{CO} 2$ and low $\mathrm{O} 2$ levels.

The complete engine combustion will also produce exhaust emission levels that conform to the allowed exhaust gas emission limits. For Indonesia, based on the Decree of the Minister of Environment No. 5 of 2005 for motorcycles, gasoline fuel is maximum CO 5.5\% and maximum HC 2400 ppm [7].

This study aims to obtain the element content and exhaust emission compounds data patterns form that characterized the category of engine combustion. This process is carried out by detecting levels of elements and exhaust emission compounds that can be detected by using electronic components of gas sensors that are sensitive to elements and compounds of $\mathrm{HC}$, $\mathrm{CO}, \mathrm{CO} 2$ and $\mathrm{O} 2$ gases $[8,9,10]$.

TABLE II

ELEMENT LEVEL AND EXHAUST EMISSION COMPOUNDS FOR THE CATEGORY OF COMPLETE COMBUSTION $[1,7]$.

\begin{tabular}{|c|l|l|}
\hline $\begin{array}{c}\text { Gas } \\
\text { Compound }\end{array}$ & Gas Level & Indicator \\
\hline $\mathrm{HC}$ & $\begin{array}{l}200 \mathrm{ppm}-400 \mathrm{ppm} \text { or } \\
0,02 \%-0,04 \%\end{array}$ & Low \\
\hline $\mathrm{CO}$ & $1,5 \%-2 \%$ & Low \\
\hline $\mathrm{CO}_{2}$ & $12 \%-15 \%$ & High \\
\hline $\mathrm{O}_{2}$ & $0,5 \%-2 \%$ & Low \\
\hline
\end{tabular}

\section{THE MATERIAL AND METHOD}

Excessive exhaust emissions indicate a waste of fuel, resulting in incomplete engine combustion [4]. Electronic fuel injection machine (Electronic Fuel Injection) uses electronic systems to regulate the system of airflow, fuel and ignition automatically resulting in perfect combustion conditions. This is evidenced by lower levels of emissions and environmentally friendly exhaust $[12,13]$.

As for engine fuel system carburettor settings, airflow system and fuel ignition system is set electro mechanically.

To detect the elements and compounds contained in exhaust emissions on engine exhaust emissions of the carburettor system, $\mathrm{O} 2$ gas sensor used $\mathrm{KE}-50, \mathrm{CO} 2$ used MG 811, CO used MQ 7 and HC used TGS $2201[8,9]$.

This system is an electronic nose (e-nose) consisting of compound sensors and integrated signal processing in an embedded system and a PC or laptop computer as a display system.

The design of the system made in this study consists of a series of sensors and signal conditioners, as well as the process of Fast Fourier Transform (FFT) as well as data normalization.

The design of this system uses hardware Field Programmable Gate Array Logic (FPGA) myRIO, National Instrument $[14,15]$. The software used for FPGA myRIO programming is data flow programming using LabVIEW, which is supported by the available libraries $[14,15]$.

The signal and signal conditioning components consist of the electronic components shown in FIG. 1.

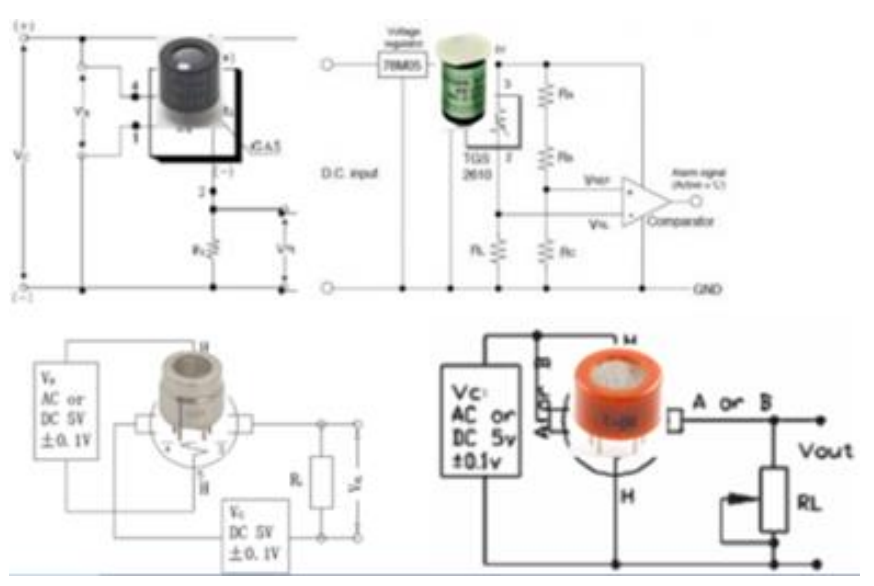

Fig 1. O2, CO2, $\mathrm{CO}$ and $\mathrm{HC}$ sensor series. 
The signal processor consists of reading the analog input data from the sensor by a certain sampling, using the myrio FPGA module from National Instrument as the target. this process is shown in figure 2 .

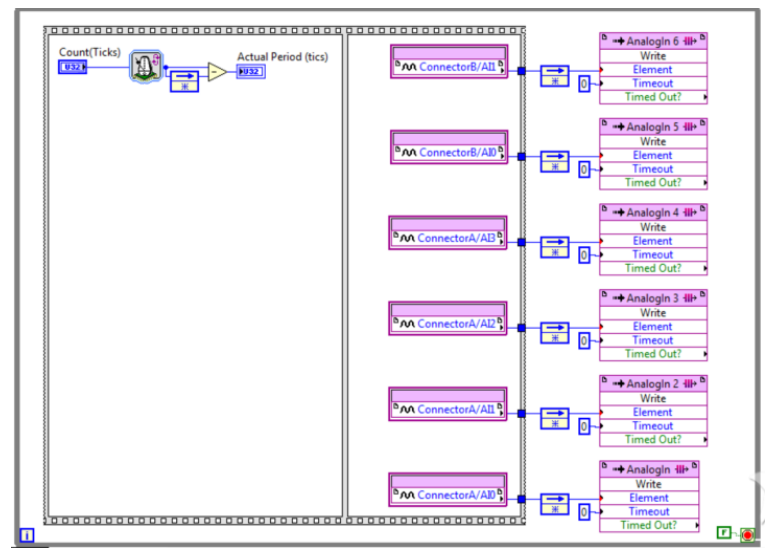

Fig 2. Analog sensor data reading on FPGA MyRIO.

The next stage is FFT, this is done to change the analog data detection sensors in time domain into analog data in the frequency domain with a certain magnitude value. This process is shown in Figure 3.

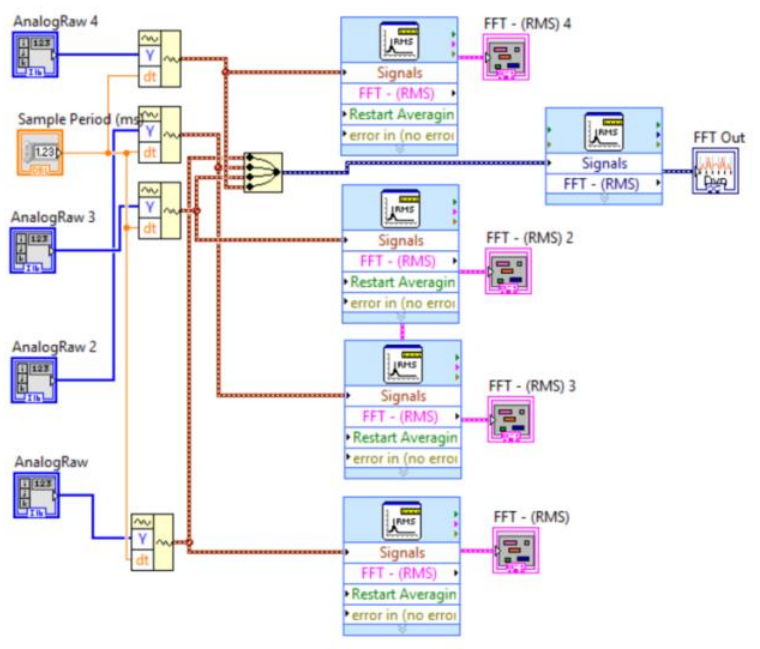

Fig 3. FFT Process on FPGA myRIO

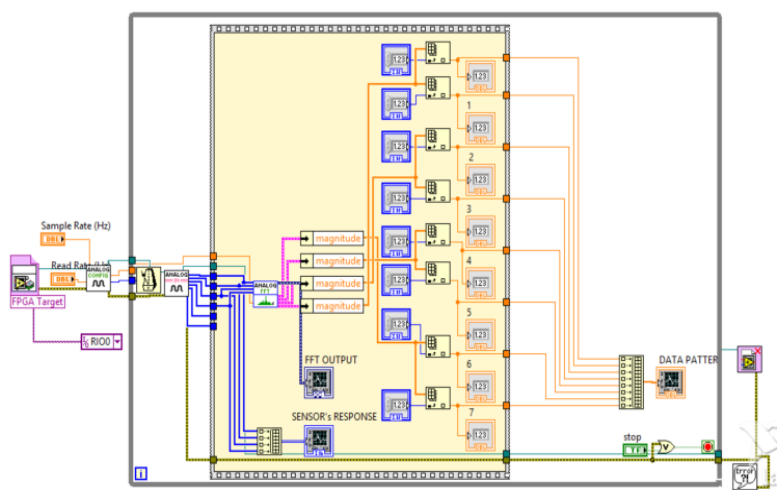

Fig 4. Data Flow Program System

The final stage is the creation of data patterns that will characterize the category of engine combustion. Data pattern obtained from the FFT is done by selecting a unique frequency that can characterize the category of engine combustion. Figure 4 shows the overall form of the program until the desired data pattern is obtained.

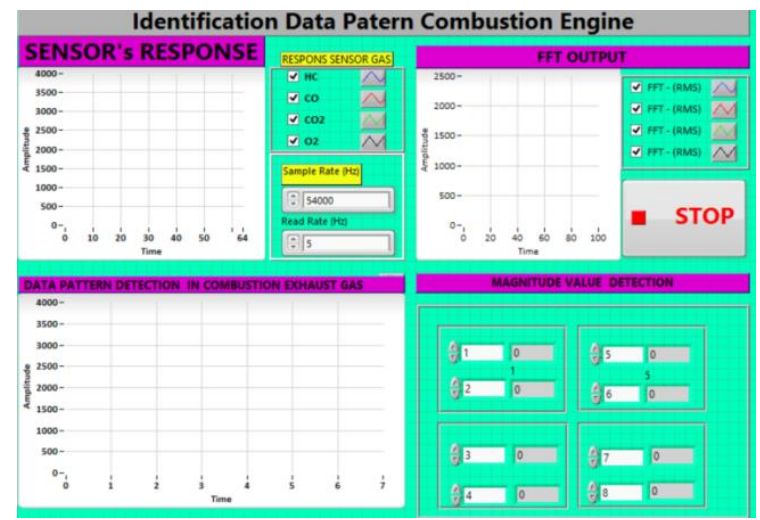

Fig 5. Virtual Instrument (VI) system using Labview Programming

\section{RESULT AND DISCUSSION}

This is an embedded system consist of modules, while the sensor components used are $\mathrm{KE} 50$ for $\mathrm{O} 2, \mathrm{MG} 811$ for $\mathrm{CO} 2$, MQ 7 for CO and TGS 2201 for HC. The test material is carburetor system car fueled gasoline and pertalite.

The testing process begins with a compound sensor response test against two groups of engine combustion conditions. The first group is a car that has not been tuned up and is known in the category of incomplete combustion. The testing process is done by placing a multi-sensor at the end of the exhaust emission channel. Furthermore, change in the value of each sensor is observed. Figure 6 shows the virtual instrument system for multi sensor responses.

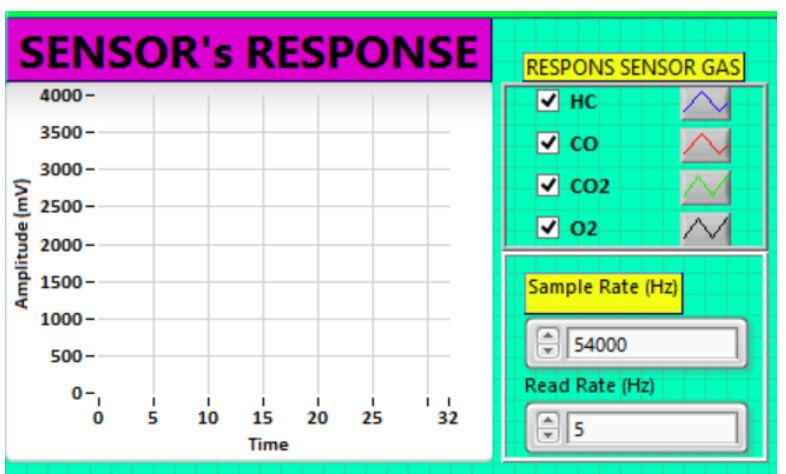

Fig 6. Virtual instrument multi-sensor response

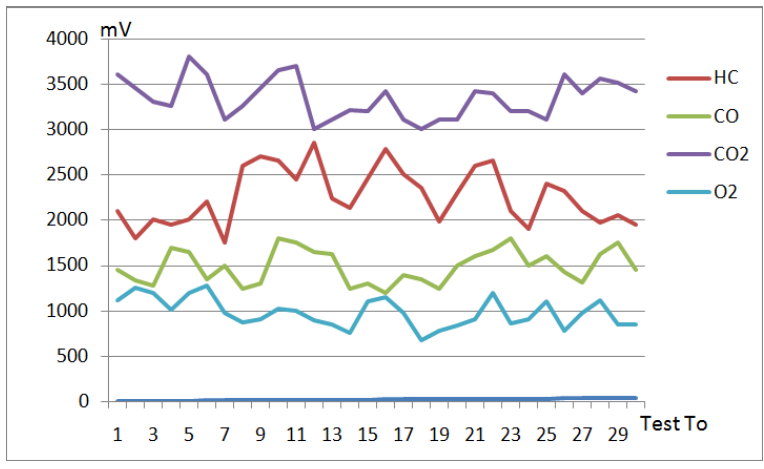

Fig 7 Results of multi sensor response to car exhaust emissions before tune up burning 
The next test is a multi-sensor response test of elements and compounds level contained in car exhaust emissions that have been in the tune-up of engine combustion and is known as complete combustion category. Multi-sensor response results are shown in Fig. 8.

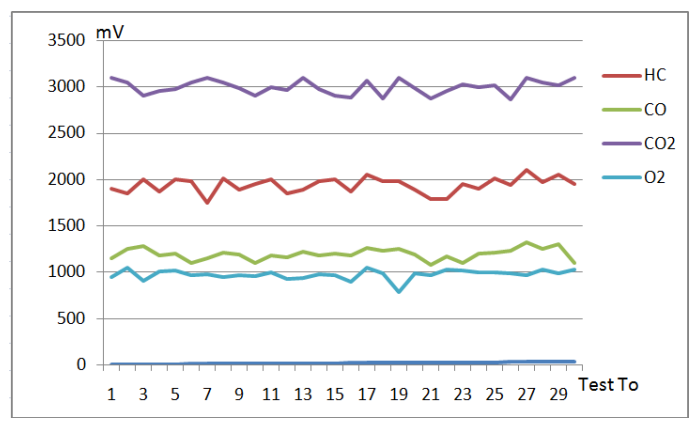

Fig 8 Multi-sensor responses to exhaust emissions car after tune-up of engine combustion.

From the data of multi-sensor response test to 2 conditions that is before and after engine combustion tune up, seen that magnitude value of each sensor relative before tune up is higher and fluctuate. Mean while, after tune up the value of magnitude is lower and stable.

Figures 9 and 10 illustrate a multi-sensor response for a Pertalite-fueled and carburetor car with an incomplete and complete combustion category system.

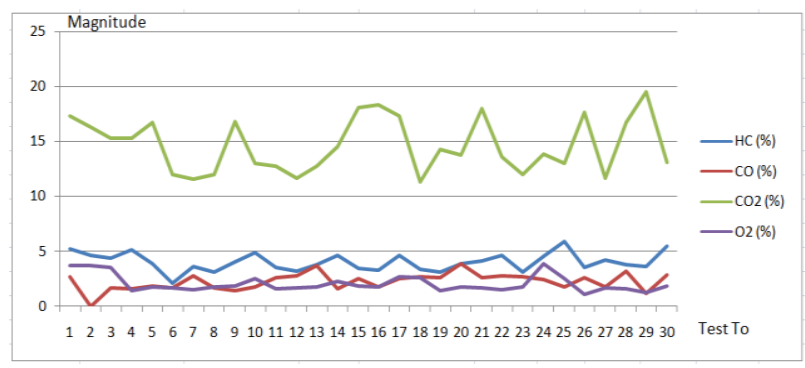

Fig 9. Multi-sensor response of a pertalite-fueled and carburetor system car with an incomplete combustion

The average value for $\mathrm{HC}=4,02 ; \mathrm{CO}=2,25 ; \mathrm{CO}_{2}=14,69$ and $\mathrm{O}_{2}=2,09$.

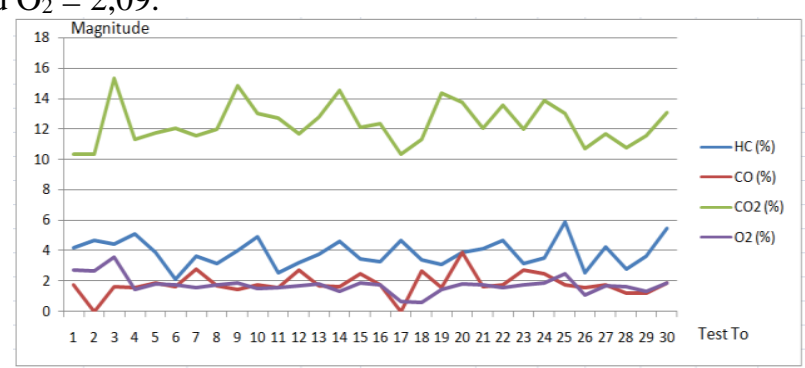

Fig 10. Multi-sensor response of a pertalite-fueled and carburetor system car with a complete combustion

Based on the sensor response result in Fig. 10, we get the average value for $\mathrm{HC}=3,86, \mathrm{CO}=1,87, \mathrm{CO}_{2}=12,67$ and $\mathrm{O}_{2}=$ 1,89 .

Furthermore, a multi-sensor response test for gasolinefueled cars with an incomplete combustion category system and complete combustion system are performed.

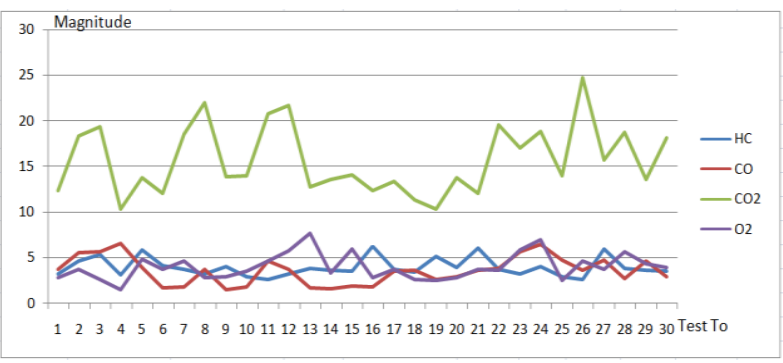

Fig 11. Multi-sensor response of a gasoline-fueled and injection system car with an incomplete combustion

The average value for $\mathrm{HC}=3.93 ; \mathrm{CO}=3.55 ; \mathrm{CO}_{2}=15.7$ and $\mathrm{O}_{2}=3.96$.

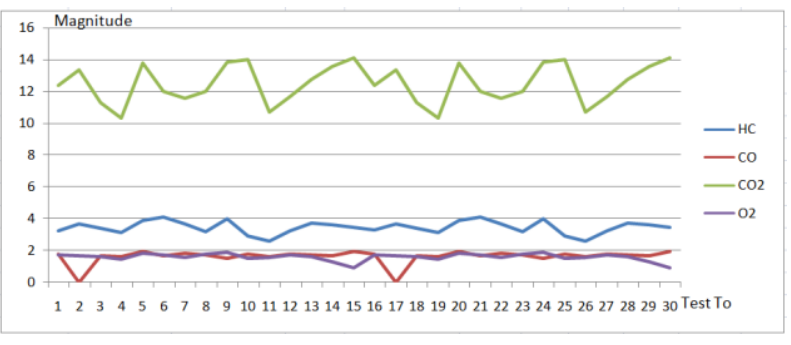

Fig 12. Multi-sensor response of a gasoline-fueled and injection system car with a complete combustion

Based on the sensor response result in Fig. 12, we get the average value for $\mathrm{HC}=3,54, \mathrm{CO}=1,79, \mathrm{CO}_{2}=12,92$ and $\mathrm{O}_{2}=$ 1,72 .

Figures 13 and 14 illustrate multi-sensor response for a Pertalite-fueled car with an incomplete combustion category system and complete combustion.

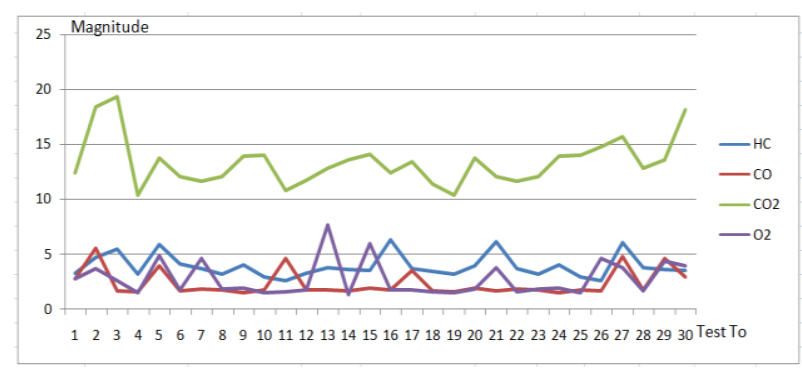

Figure 13. Multi-sensor response of a gasoline-fueled and injection system car with an incomplete combustion

From figure 13 can be obtained that the average value of $\mathrm{HC}=3.86 ; \mathrm{CO}=2.32 ; \mathrm{CO}_{2}=13.32$ and $\mathrm{O}_{2}=2.72$.

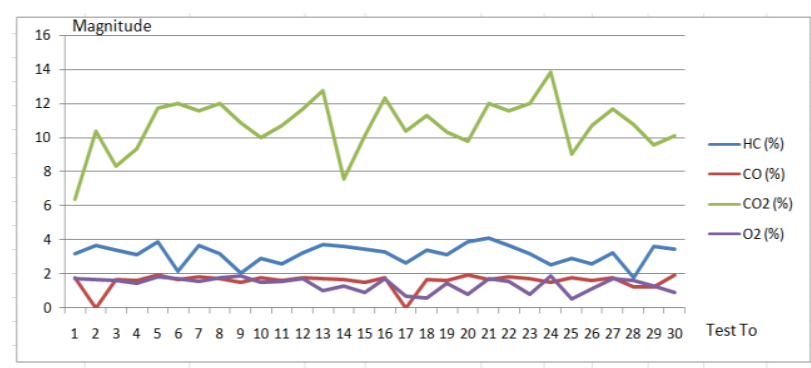

Figure 14. Multi-sensor response of a pertalite-fueled and injection system car with an incomplete combustion 
Average value of $\mathrm{HC}=3,16 ; \mathrm{CO}=1,69 ; \mathrm{CO}_{2}=10,7$ and $\mathrm{O}_{2}=1.39$.

Furthermore, the test is done in displaying emission gas emission data pattern. The testing process carried out on two conditions before the tune-up process of incomplete combustion and after the tune-up process of perfect combustion.

Figure 15 shows the detected data pattern Virtual instrument display. The amount of data selected is 8 frequencies of 32 frequencies displayed by FFT process. These frequencies indicate a unique data pattern shape that characterizes the emission and exhaust gas by category of combustion.

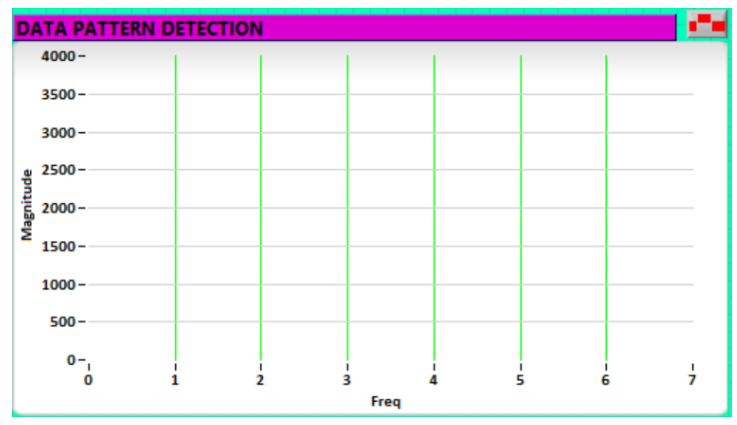

Figure 15. Virtual Instrument detection data pattern

The test before the tune up is displayed in the form of a graph of the data pattern in figure 16.

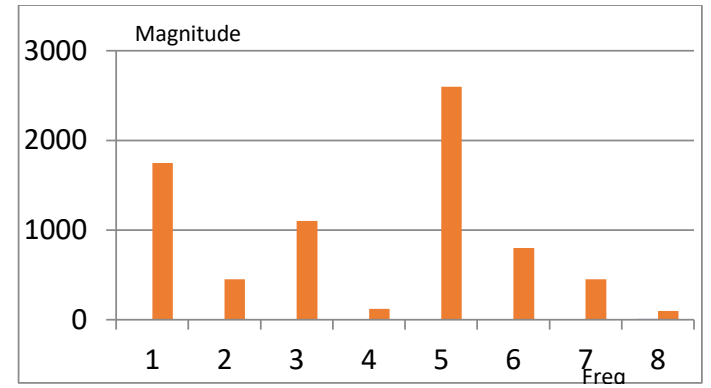

Fig 16. Pattern of exhaust emissions data prior to tune up the combustion of gasoline-fueled engine car

Figure 16 is a data pattern of pertalite-fueled car. From the data pattern obtained, it can be seen that there is a decrease in the magnitude of each pattern.

The next test is displaying the data pattern after tune up process of complete combustion engine. Test results are shown in figure 17.

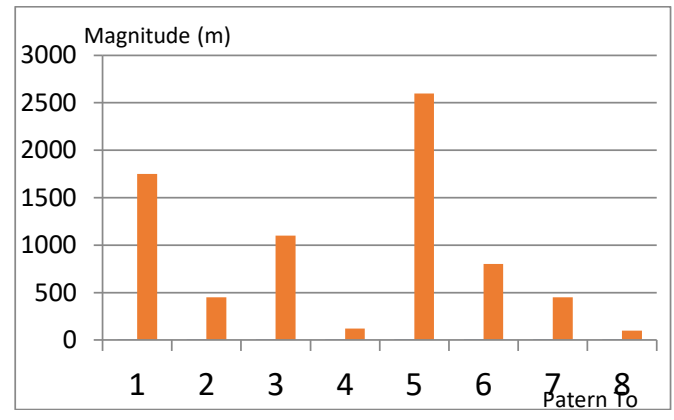

Fig 17. Exhaust emissions data pattern before tuning up the combustion of a pertalite-fueled car

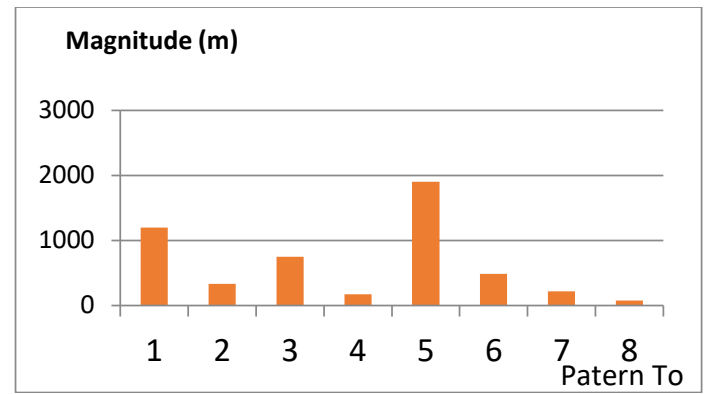

Fig 18. Exhaust emissions data pattern after tuning up the combustion of a pertalite-fueled car

To compare the pattern detection results obtained by the system that is made, the comparison of the test results with the emission level test results is done. The emission level test is performed on the same car before and after engine combustion tune-up. The emission level test results are shown in table 3 .

TABLE III

Emission Test Result Before AND AFter Tune Up MACHINE COMBUSTION

\begin{tabular}{|l|l|l|}
\hline $\begin{array}{c}\text { Emission } \\
\text { Compound }\end{array}$ & BeforeTune Up & AfterTune Up \\
\hline $\mathrm{HC}$ & $800 \mathrm{ppm}$ & $315 \mathrm{ppm}$ \\
\hline $\mathrm{CO}$ & $4,8 \%$ & $1,8 \%$ \\
\hline $\mathrm{CO} 2$ & $27 \%$ & $13 \%$ \\
\hline $\mathrm{O} 2$ & $2,3 \%$ & $1,1 \%$ \\
\hline
\end{tabular}

By comparing the results of table 3 and table 2 as reference data, the emission levels seen before the engine tune-up is an incomplete combustion engine condition. Meanwhile, after the tune up process is done, obtained complete combustion conditions.

Further tests were conducted on several cars with various manufacturing and product years. The number of vehicles tested was 5 units between 1987 and 1995.

Test results aimed to determine the condition of the burning of the vehicle based on the pattern of data used as a reference or reference. Testing is done by comparing the similarity of reference data pattern with data pattern of detection result. The tested vehicles are the one that has not been tuned up or in unknown conditions of combustion engine. Table 4 shows the identification results of vehicle engine combustion categories tested by reference to the data pattern of complete combustion conditions.

TABEL IV

EMission Test Result Of DATA PATTERN OF COMBUSTION TyPES OF MOBILE

\begin{tabular}{|l|l|l|}
\hline \multicolumn{1}{|c|}{$\begin{array}{c}\text { Type of } \\
\text { vehicle }\end{array}$} & $\begin{array}{c}\text { Manufacturing } \\
\text { Year }\end{array}$ & $\begin{array}{c}\text { Combustion Data } \\
\text { Pattern Identification } \\
\text { Result }\end{array}$ \\
\hline Kijang Super & 1987 & Incomplete \\
\hline $\begin{array}{l}\text { Toyota Twin } \\
\text { Cam }\end{array}$ & 1990 & Complete \\
\hline Kijang Super & 1991 & Complete \\
\hline $\begin{array}{l}\text { Totoyota } \\
\text { Corolla Great }\end{array}$ & 1993 & Complete \\
\hline $\begin{array}{l}\text { Toyota kijang } \\
\text { super }\end{array}$ & 1992 & Incomplete \\
\hline
\end{tabular}


The next test is the similarity test pattern data detected by system with reference data pattern of certain combustion categories. The tested car is a car that has been known its burning conditions. The test is being done 30 times. Results data are shown in table 5 for complete burning category similarity tests.

From 30 times test, there is similarity of data pattern of complete combustion as much as 25 times or with percentage of success $83,33 \%$.

Similarity test is done to a car which has complete combustion engine as shown in table 6 . The system ability showing the similarity of incomplete combustion is $90 \%$

TABLE V

THE RESULT OF SIMILARITY TEST OF DATA PATTERN AFTER TUNE UP PROCESS / COMPLETE BURNING CATEGORY

\begin{tabular}{|c|l|}
\hline $\begin{array}{c}\text { Number of } \\
\text { Test }\end{array}$ & \multicolumn{1}{|c|}{ Combustion Data Pattern } \\
\hline 1 & Complete \\
\hline 2 & Complete \\
\hline 3 & Incomplete \\
\hline 4 & Complete \\
\hline 5 & Complete \\
\hline 6 & Complete \\
\hline 7 & Complete \\
\hline 8 & Complete \\
\hline 9 & Complete \\
\hline 10 & Incomplete \\
\hline 11 & Complete \\
\hline 12 & Complete \\
\hline 13 & Complete \\
\hline 14 & Complete \\
\hline 15 & Complete \\
\hline 16 & Complete \\
\hline 17 & Complete \\
\hline 18 & Complete \\
\hline 19 & Complete \\
\hline 20 & Complete \\
\hline 21 & Complete \\
\hline 22 & Incomplete \\
\hline 23 & Complete \\
\hline 24 & Complete \\
\hline 26 & Complete \\
\hline 28 & Complete \\
\hline 30 & Complete \\
\hline & Incomplete \\
\hline 29 & Complete \\
\hline
\end{tabular}

TABEL VI

THE RESULT OF SIMILARITY TEST OF DATA PATTERN AFTER TUNE UP PROCESS / INCOMPLETE BURNING CATEGORY

\begin{tabular}{|c|l|}
\hline $\begin{array}{c}\text { Number of } \\
\text { Test }\end{array}$ & \multicolumn{1}{|c|}{$\begin{array}{c}\text { Combustion Data Pattern } \\
\text { Result }\end{array}$} \\
\hline 1 & Incomplete \\
\hline 2 & Incomplete \\
\hline 3 & Incomplete \\
\hline 4 & Incomplete \\
\hline 5 & Incomplete \\
\hline 6 & Complete \\
\hline 7 & Incomplete \\
\hline 8 & Incomplete \\
\hline 9 & Complete \\
\hline 10 & Incomplete \\
\hline 11 & Incomplete \\
\hline 12 & Incomplete \\
\hline 13 & Incomplete \\
\hline 14 & Incomplete \\
\hline 15 & Incomplete \\
\hline
\end{tabular}

\begin{tabular}{|l|l|}
\hline 16 & Incomplete \\
\hline 17 & Incomplete \\
\hline 18 & Incomplete \\
\hline 19 & Incomplete \\
\hline 20 & Incomplete \\
\hline 21 & Incomplete \\
\hline 22 & Incomplete \\
\hline 23 & Incomplete \\
\hline 24 & Complete \\
\hline 25 & Incomplete \\
\hline 26 & Incomplete \\
\hline 27 & Incomplete \\
\hline 28 & Incomplete \\
\hline 29 & Incomplete \\
\hline 30 & Complete \\
\hline
\end{tabular}

\section{IV.CONCLUSION}

Based on the results of research and data analysis conducted in this study can be summarized as follows: Sensor magnitude value is relatively highly fluctuated before combustion tune-up. Data pattern magnitude of fueledpertalite car is lower that fueled-gasoline car.

There is a difference between both magnitude values of combustion data pattern, which where the complete combustion data pattern is lower than the incomplete ones. The system ability showing similar data pattern of complete combustion is $83,3 \%$ while incomplete combustion is $90 \%$

\section{ACKNOWLEDGMENT}

Thanks to Simlitabmas Kemenristekdikti and P3M Politeknik Negeri Padang who have funded this research in 2017.

\section{REFERENCES}

[1] Gerhard Knothe,Christopher A. Sharp , and Thomas W. Ryan http://id.wikipedia.org/wiki/ exhaust emissions . akses 29 Maret 2017.

[2] Andrizal, Rivanol Chadry, Budhi Bachtiar,"Detection Combustion Data Pattern on Gasoline Fuel Motorcycle with Carburetor System", Vol 6, No 1, IJASEIT, page 107-111, 2016.

[3] Andrizal, Rusfandi, Rivanol Chadry," Sum Square Error Methods implementation For Combustion Categorizing Identification in 4 Stroke Engine Gasoline Fuel Motorcyle, Vol 11, No 2, Polirekayasa, halaman 1-10, 2016

[4] Isnanda,"Pengaruh Gas Buang Terhadap Kinerja Motor Bensin", Volume 4 No 2 tahun 2007, Jurnal Teknik Mesin, Politeknik Negeri Padang.

[5] Mustafa Bakeri, Akhmad Syarief, Ach. Kusairi," Analisa gas buang mesin berteknologi EFI dengan bahan bakar premium”, INFO TEKNIK, Volume 13 No. 1, Juli 2012.

[6] Beni Setya Nugraha, S.Pd.T,"Aplikasi Teknologi Injeksi Bahan Bakar Elektronik (EFI) Untuk Mengurangi Emisi Gas Buang Sepeda Motor”, Volume 2 No 5 Nofember 2007, D3 Teknik Mesin Universitas Negeri Semarang.

[7] Mohd. Gempur Adnan,"Ambang batas emisi gas buang kendaraan bermotor lama" Peraturan Menteri Negara

Lingkungan no 5 tahun 2006.

[8] Figaro Group,"Product Information Figaro OxygenSensor SK25F", <url:http://www.figaro.com/>, 2014. akses 29 Maret 2107.

[9] Hanwei electronics,mg-811 data sheet, http://www.hwsensor.com. Akses 5 Maret 2017.

[10] Ahmed Soliman, Prabhu J.Jackson,Giorgio Rizzoni and Prabir Dutta,"A sensor array for control of_engine exhaust after-treatment system",skoge/prost/proceedings/ifac 2005

[11] Keith Moore, National instruments application notes," Testing Automotive Exhaust Emissions,". 2013.

[12] Beny Setia Nugra, Application technology electronic fuel injection (EFI) to reduce exhaust emissions of motorcycles, published by the Journal of Scientific and Applied Technology program D3 Mechanical 
Engineering, Faculty of Engineering, State University of Semarang volume 5 number 2 in 2007.

[13] Joko Winarno,"Study of exhaust emissions of petrol-engined vehicles in various brands of vehicles and the year of manufacture', published by the Journal of Engineering, Faculty of Engineering, University of Jogyakarta Janabadra Volume 4 Number 1 in 2014
[14] National Instruments,"NI myRIO Design Real Time System,fast<url: htp://ftp.ni.com/pub/.../myrio_do_engineering_nid14.pdf>, 2014 akses 22 Juni 2017

[15] National Instrument,"Getting Started With LabVIEW FPGA,", <www.ni.com > Tutorials>, 2016.Akses 5 Mei 2017. 